\title{
Ekonomie en die bestudering van fratse
}

Freakonomics: a rogue economist explores the hidden side of everything

Steven D Levitt and Stephen J Dubner

ISBN-13: 978-0-06-114330

ISBN-10: 0-06-114330-8

HarperTorch Publishers, New York, 2006.

Resensie deur Johann Tempelhoff

Noordwes-Universiteit

Freakonomics is 'n boek waarin die benaderingswyse tot ekonomie van Steven D Levitt 'n jong Amerikaanse ekonoom deur die joernalis en skrywer Stephen J Dubner uiteengesit word. Levitt (voorgraads Harvard en 'n PhD van MIT) het opgang gemaak nadat hy in 2003 die gesogte John Bates Clark-medalje ('n toekenning aan die top-ekonoom, onder die ouderdom van 40 jaar, in die Verenigde State van Amerika) gewen het.

Levitt beskik, onder andere, oor die uitsonderlike vermoë om die uitsonderlike gegewens in lang statistiese tabelle te identifiseer en dan op 'n uitsonderlike manier te interpreteer. Nog meer, deur die gebruikmaking van ekonomiese teorie het hy ten doel om sosio-ekonomiese knelpunte (onder meer veral kriminologiese verskynsels) in die samelewing te identifiseer.

Hy vra interessante vrae aan die werklikheid en kom dan met merkwaardige resultate na vore. Voorbeelde van die tipe vrae wat hy geneig is om te stel, sluit in: Wat het onderwysers en sumostoeiers gemeen? Hoekom is die Klu Klux Klan soos eiendomsagente? Waarom woon dwelmhandelaars by hul ma's? Wat het van al die misdadigers geword? Wat maak die perfekte ouer? Hoe moet te werk gegaan word om by Harvard uit te kom?

Levitt se benaderingswyse is om statistiese gegewens te soek wat onregstreeks op sy ondersoekveld van toepassing is. Deur die afwykings te identifiseer soek hy, letterlik soos 'n speurder, na die onderliggende 
oorsake van die tendens. Soms maak hy gebruik van vergelykende metodoes uit oënskynlik kontrasterende sosiale verskynsels om by analises uit te kom,

Byvoorbeeld, die geskiedenis van die Klu Klux Klan (KKK) word beskou vanuit die perspektief van die onderliggende ekonomiese dryfkragte wat hierdie organisasie so 'n belangrike rol laat speel het in die twintigste eeuse Amerikaanse suide. Die allesomvattende benaderingswyse van 'n rassebenadering tot die werklikheid, het ook sy invloed op die ekonomiese handelinge van die mense wat die ideologie van die KKK onderskryf.

Deur bloot op die geskiedenis in te gaan, stel Levitt vas, hoe lede van die KKK se leierskap, deur middel van die verhandeling in sekuriteit en versekering eintlik 'n misdaadonderneming geword het. Deur aspekte van die KKK se strategieë te vergelyk met die wyse waarop eiendomsagente te werk gaan om hulself deur die proses van selektiewe verhandeling van vaste eiendom verryk wys hy op die fyn skeiding tussen misdaad en sakepraktyk.

'n Ander voorbeeld van Levitt se benaderingswyse is 'n ondersoek na die afname van misdaad in New York. Tradisioneel is aanvaar dat die beleid van 'zero tolerance' van burgemeester Rudolph Guliani daartoe meegewerk het om misdaad drasties in die negentigerjare te laat afneem.

Ofskoon Levitt dit gedeeltelik aanvaar, is hy geneig om, aan die hand van ander navorsers, daarop te wys dat sterk optrede teen misdaad in New York, eintlik reeds deur Giulini se voorgangers, in samewerking met die polisie beplan is. Die sukses van die veldtog het daartoe gelei dat die insidensie van moord van 2245 in 1990 tot 596 in 2003 afgeneem het. Levitt soek die verklaring vir die afname in die demografiese siklustendense van die VSA.

Die antwoord is gesetel in die deurslaggewende 1973-hofbeslissing rondom Norma McCorvey (alias Me Roe) wat daartoe aanleiding gegee het dat aborsie in sommige deelstate wettiglik uitgevoer kon word. Daardeur, verduidelik Levitt, het die onbeperkte geboortes van mense in die armoedige lae van die samelewing aansienlik afgeneem.

Teen die negentigerjare het vrywillige asborsies spreekwoordelik soos die skoenlapper, wie se vlerkklap op die een kontinent plaasvind en dan op 'n ander kontinent die uitwerking laat geld, die gevolg gehad dat ' $n$ misdadige jeugelement uit die samelewing begin verdwyn het. Daarmee saam is ongeletterdheid, dwelmgebruik en misdaad, in 'n groot mate hok geslaan.

Ofskoon heelwat van Levitt se aannames oorlede Jeremy Bentham kinderlik gelukkig sou maak, het sy benaderingswyse ook 'n sagter kant. Veral waar dit gaan oor ouerskap en die gesin, die traumatiese 
verlies van kindersterftes. Dit is 'n trauma wat Levitt en sy vrou in hul persoonlike lewe deurgemaak het. Later het dit die onderwerp van sy navorsing geword.

Freakonomics is 'n leesbare boek. Daar is verwysings in die werk. Ook is daar interessante teoretiese uitgangspunte, wat op 'n hoogs verstaanbare manier oorgedra word. Die joernalistiese inslag van Levitt se skyfvennoot, Steven J Dubner, wat onder meer ook vir die New York Times skryf, kom duidelik in die werk na vore. Vir die ekonoom wat oor 'n baie breër spektrum na die dinge van die wêreld wil kyk, is hierdie boek gepaste leesstof. 